\title{
Evolution of an Invasive Species Research Program and Implications for Large-scale Management of a Non-native, Invasive Plant Pathogen
}

\author{
Christopher A. Lee ${ }^{1}$, Janice M. Alexander ${ }^{1}$, Susan J. Frankel ${ }^{2} \&$ Yana Valachovic $^{1}$ \\ ${ }^{1}$ University of California Cooperative Extension, USA \\ ${ }^{2}$ USDA Forest Service, Pacific Southwest Research Station, USA \\ Correspondence: Janice M. Alexander, University of California Cooperative Extension, 1682 Novato Boulevard, \\ Suite 150B, Novato, CA 94947. Tel: 1-415-473-4204. E-mail: jalexander@ucdavis.edu
}

Received: January 19, 2012 Accepted: February 14, 2012 Online Published: June 1, 2012

doi:10.5539/enrr.v2n2p99 URL: http://dx.doi.org/10.5539/enrr.v2n2p99

\begin{abstract}
We conducted a research needs assessment (RNA) in 2010 to gather opinions of "experts" and a larger public on research priorities for Phytophthora ramorum, the pathogen that causes sudden oak death in forest trees and Ramorum blight in ornamental plants. We place these 2010 findings in context with findings of similar $P$. ramorum needs assessments from 2002 and 2007-2008 and with a comprehensive literature review published in 2010. P. ramorum research needs have evolved from an emphasis on basic biological information toward an emphasis on management. As with many other non-native, invasive organisms, a major challenge remains how to move P. ramorum research into more wide-scale, unified attempts at management. Our analysis suggests that successfully moving from basic research to on-the-ground management requires overcoming the tendency toward specialized, limited viewpoints and providing stakeholders a comprehensive, integrated picture of the necessity and possibility of managing this plant disease.
\end{abstract}

Keywords: research needs assessment, Phytophthora ramorum, sudden oak death, invasive species management

\section{Introduction}

Research needs assessments (RNAs) are important tools that allow scientists, research organizations, and policy makers to assess the state of knowledge and identify the most fruitful areas for future research. A cursory review of the scientific literature reveals numerous RNAs, often conducted at regular intervals. The existence of RNAs within a field of study indicates a degree of disciplinary self-awareness and care for the progress of the field.

However, study of RNAs can also serve a broader metadisciplinary purpose. Periodic assessments of progress in a scientific field allow observers to reflect on how research topics accrue and how bodies of knowledge assemble around topics of contemporary importance. In each discipline, is there a predictable pattern of broad issues that are typically tackled first, with auxiliary issues treated successively? For example, do researchers in fields related to biology first study basic biology, then real-world applications, then social dimensions of the topic? What role does funding or lack of funding play in facilitating, impeding, or shaping scientific research? How does the scale of application - for example, individuals versus populations - shape basic biological research?

Like other scientists, biologists who study invasive insects and diseases conduct RNAs. In this paper, we report the results of one such RNA, conducted for research on the non-native, invasive plant pathogen Phytophthora ramorum, (cause of sudden oak death and other diseases), and we discuss what the evolution of $P$. ramorum RNA results over a period of 10 years, supplemented by a recent review of research literature (Kliejunas, 2010), has to show about maturing knowledge in the understanding of this invasive pathogen. In particular, this examination can help illuminate the discussion surrounding how best to link basic scientific research with on-the-ground management of invasive organisms in natural ecosystems, a question that has engaged many conservation biologists in recent years. Examining the evolution of RNAs conducted for P. ramorum in the ten years since the pathogen was discovered reveals some patterns and recurring issues that could help scientists studying future invasive pathogens to move more quickly from basic research to mature management programs. It may also reflect similar patterns that underlie research programs conducted for other invasive insects, pathogens, or plants, thus making conclusions gleaned from this project applicable to management of those organisms as well.

1.1 Background on P. ramorum and Sudden Oak Death Research 
Over a decade has passed since P. ramorum was recognized as the cause of sudden oak death in the United States (Werres et al., 2001; Rizzo et al., 2001). In that time, sudden oak death has killed more than an estimated 1 million trees in coastal California and Oregon (Meentemeyeret al., 2008), has killed or contributed to the loss of over half a million trees in the United Kingdom (Webber et al., 2010), and has been detected in U.S. ornamental nurseries over 400 times (USDA APHIS, 2011). Despite quarantines in the United States, European Union, and many other countries (Sansfordet al., 2009), P.ramorum remains a threat to forests and nurseries nationwide. The USDA-Forest Service, Pacific Southwest Research Station (PSW) has funded a P. ramorum research program since 2000 to provide a scientific basis for response programs and to develop management techniques to prevent or mitigate the effects of the pathogen. Researchers have provided the foundation for diagnostic, monitoring, management and regulatory programs for this pathogen and for prevention of future exotic pest introductions (see Kliejunas, 2010 and www.suddenoakdeath.org).

During the existence of this research program, funders and facilitators have conducted periodic RNAs to ensure that funding flows to solve the most pressing needs for new knowledge according to the mainstream of scientific opinion on the subject. P. ramorum RNAs were initially limited in scope and participation, but by 2007, a more public process emerged through an RNA workshop at the Sudden Oak Death Third Science Symposium. Three years later, PSW and the California Oak Mortality Task Force (COMTF) partnered on a 2010 RNA for Phytophthora ramorum. The purpose of the 2010 RNA was to assess current research needs for the pathogen in both nurseries and wildlands.

\section{Methods}

\subsection{Survey}

Following a model presented by Wolf and Kruger (2010), we conducted the 2010 RNA through anonymous online questionnaires using a 2-phase Delphi model. To conform to the Delphi model, a list of "expert" participants was generated based on subject matter experience, with subsets strategically selected to provide a diverse base of affiliations. More than 80 experts representing academia and nonprofits; industry and land management; and local, state, and federal agencies were recruited for the assessment. We developed, pre-tested, and finalized the Delphi questions and then invited expert participants. All responses were anonymous.

We also extended our reach beyond Delphi "experts" to include the participation of the more generally experienced members of the P. ramorum community (hereafter referred to as "community"). We advertised participation through the COMTF website (www.suddenoakdeath.org) and numerous professional e-mail lists. We then ran two rounds of four simultaneous surveys each: Expert Nursery, Community Nursery, Expert Wildland, and Community Wildland. In this way, we were able to follow Delphi guidelines for smaller surveys of invited content experts while also broadening the survey out to a larger audience.

Questions were posed through the University of California's online Survey Tool. The two Delphi rounds were administered over a 3-month time span (roughly March 15 to June 15, 2010). In round 1, participants were asked to (1) list the three most important $P$. ramorum research questions and (2) their professional affiliation (academic; management/industry; or government). This phase took place from mid to late March 2010.

At the close of round 1, responses were sorted into 10-11 broad categories. Round 2 took place from late April to mid-May 2010 and respondents could participate regardless of their participation in the previous round. In round 2, participants were asked to rank the categories of issues submitted from round 1 using a Likert scale where $1=$ very low priority and $5=$ very high priority. Mean responses were calculated for each category.

During the query phase (Delphi round 1), there were 61 expert responses with an additional 125 community responses for 186 total responses. For the ranking phase (Delphi round2), there were 50 experts responding plus 179 community members for 229 total responses. Responses were fairly well distributed across affiliations (academic $=38 \%$; management $=25 \%$; government $=44 \%$ ).

\subsection{Comparison of Respondent Groups}

Within each broad survey (wildland and nursery), we compared the responses of expert and community respondents by using NCSS 2007 (Hintze, 2007) for a cross-tabulation analysis. For each research category, we calculated a chi-square statistic and associated p-value that captured significant differences between the two groups' prioritizations on the 1-5 scale.

\subsection{Comparison with Past Years}

To compare the 2010 RNA results against previous years' research priorities, we referenced "Sudden oak death: A 5-year Research Plan" (PSW, 2002), the 2007 RNA results (COMTF, 2007) and the 2008 COMTF Nursery 
Committee Research Needs (COMTF, 2008b). These three documents provided lists of research questions that had been agreed upon and prioritized by various groups at the time. The methodologies of these previous efforts differ from that of the 2010 RNA, but the outcome is similar - a prioritized list of research projects for that time. In order to compare the research priorities at the three time points - 2002, 2007-2008, and 2010 - we needed to convert all responses to a common unit. We took each individual research question and assigned it to one of the categories used in our 2010 prioritization effort. We then assigned a priority rank based on the frequency each category appeared, with the most frequently appearing categories receiving the higher priorities.

\subsection{Literature Review}

To compare perceived research gaps identified during the RNA process to actual gaps in the published literature, we assigned 345 published works of $P$. ramorum research indexed in the comprehensive literature review of Kliejunas (2010) to the research categories identified above for wildlands and nurseries. We limited our counts to peer-reviewed articles and counted each paper in only the one category that was deemed most relevant. For example, in the case of Mascherettiet al. (2008), which clarifies genetic relationships between various isolates of P. ramorum in order to reconstruct pathogen spread across parts of California, we assigned it to the "Spread in Forests" category rather than to the "Pathogen Characterization" category.

\section{Results}

\subsection{RNA Results}

Results were ranked from highest priority (1) to lowest priority (up to 11); the lower the number, the higher the priority. The research need categories that received the highest ranking in the wildland area include: "Evaluation of management approaches" (expert rank =1, community rank =3); "Spread in forests" $(2,1)$; "Eradication and remediation" $(3,2)$; and "Detection and diagnostics" $(4,4)$. The community also highly ranked (mean $>4)$ the category "Ecological impacts." See Table 1 for the full ranking results for wildlands.

Table 1. Comparison of wildland/forestry "expert" and "community" responses when asked to rank the most important sudden oak death research needs $(1=$ very low priority, 5 = very high priority $)$ for Round 2 of the Delphi survey. For the chi-square (cross-tabulation) analysis of significant differences between the two groups' responses, $\alpha=0.05$. Significant differences are shown in bold.

\begin{tabular}{|c|c|c|c|c|c|c|c|c|c|}
\hline & & Expert R & ponde & & & ommunity & espon & lents & \\
\hline Research Category & Rank & $\begin{array}{c}\text { Mean } \\
\text { response }\end{array}$ & SE & $\begin{array}{c}\text { Mode } \\
\text { response }\end{array}$ & Rank & $\begin{array}{c}\text { Mean } \\
\text { response }\end{array}$ & $\mathrm{SE}$ & $\begin{array}{l}\text { Mode } \\
\text { response }\end{array}$ & $\begin{array}{c}\text { Chi-square } \\
\text { P-value }\end{array}$ \\
\hline $\begin{array}{c}\text { Evaluationofmanagement } \\
\text { approaches }\end{array}$ & 1 & 4.70 & 0.10 & 5 & 3 & 4.20 & 0.10 & 5 & 0.06 \\
\hline Spread in forests & 2 & 4.52 & 0.19 & 5 & 1 & 4.37 & 0.08 & 5 & 0.07 \\
\hline $\begin{array}{l}\text { Eradication \& } \\
\text { remediation }\end{array}$ & 3 & 4.13 & 0.22 & 5 & 2 & 4.22 & 0.12 & 5 & 0.64 \\
\hline Detection \& diagnostics & 4 & 3.87 & 0.22 & 4 & 4 & 4.03 & 0.11 & 5 & 0.84 \\
\hline Ecological impacts & 5 & 3.69 & 0.19 & 4 & 5 & 4.00 & 0.09 & 4 & 0.23 \\
\hline $\begin{array}{l}\text { Host plants (including } \\
\text { resistance) }\end{array}$ & 6 & 3.35 & 0.21 & 3 & 7 & 3.68 & 0.95 & 4 & 0.35 \\
\hline $\begin{array}{l}\text { Human dimensions of } \\
\text { management (regulatory } \\
\& \text { policy) }\end{array}$ & 7 & 3.30 & 0.20 & 3 & 9 & 3.44 & 0.12 & 3 & 0.77 \\
\hline Restoration & 8 & 3.22 & 0.21 & 4 & 6 & 3.75 & 0.12 & 3 & 0.04 \\
\hline $\begin{array}{l}\text { Social \& economic } \\
\text { impacts }\end{array}$ & 9 & 3.04 & 0.18 & 3 & 10 & 3.15 & 0.12 & 3 & 0.62 \\
\hline Pathogen characterization & 10 & 3.00 & 0.20 & 3 & 8 & 3.5 & 0.12 & 3 & 0.34 \\
\hline
\end{tabular}

For the nursery area (see Table 2), the most highly ranked categories included: "Best Management Practices" (expert rank =1, community rank =1); "Eradication and remediation" $(2,3)$; "Diagnostics and detection" $(3,2)$; and "Pathogen characterization and spread" $(4,4)$. There was slightly less agreement on further categories, with experts highly ranking (mean $>4$ ) the research topics "Potting media and soils under pots" and "Water" while the community highly ranked "Hosts and symptoms." 
Table 2. Comparison of nursery "expert" and "community" responses when asked to rank the most important sudden oak death research needs ( 1 = very low priority, $5=$ very high priority) for Round 2 of the Delphi survey. For the chi-square (cross-tabulation) analysis of significant differences between the two groups' responses, $\alpha=$ 0.05. 1The community nursery survey, Round 1, included no submitted research questions that fell into the category "Economic Impacts," so this category was not included in Round 2 of the survey.

\begin{tabular}{cccccccccc}
\hline & \multicolumn{3}{c}{ Expert Respondents } & \multicolumn{7}{c}{ Community Respondents } \\
\hline $\begin{array}{c}\text { Research } \\
\text { Category }\end{array}$ & Rank & $\begin{array}{c}\text { Mean } \\
\text { response }\end{array}$ & SE & $\begin{array}{c}\text { Mode } \\
\text { response }\end{array}$ & Rank & $\begin{array}{c}\text { Mean } \\
\text { response }\end{array}$ & SE & $\begin{array}{c}\text { Mode } \\
\text { response }\end{array}$ & $\begin{array}{c}\text { Chi-square } \\
\text { P-value }\end{array}$ \\
$\begin{array}{c}\text { management } \\
\text { practices }\end{array}$ & 1 & 4.56 & 0.12 & 5 & 1 & 4.42 & 0.07 & 5 & 0.63 \\
$\begin{array}{c}\text { Eradication \& } \\
\text { remediation }\end{array}$ & 2 & 4.44 & 0.19 & 5 & 3 & 4.26 & 0.09 & 5 & 0.58 \\
$\begin{array}{c}\text { Detection \& } \\
\text { diagnostics }\end{array}$ & 3 & 4.30 & 0.18 & 5 & 2 & 4.29 & 0.09 & 5 & 0.63 \\
$\begin{array}{c}\text { Pathogen } \\
\text { characterization } \\
\quad \text { spread }\end{array}$ & 4 & 4.26 & 0.15 & 4 & 4 & 3.97 & 0.08 & 4 & 0.32 \\
$\begin{array}{c}\text { Potting media } \\
\& \text { soils under }\end{array}$ & 5 & 4.12 & 0.19 & 5 & 9 & 3.52 & 0.11 & 4 & 0.08 \\
$\begin{array}{c}\text { pots } \\
\text { Water }\end{array}$ & 6 & 4.00 & 0.21 & 5 & 7 & 3.63 & 0.10 & 4 & 0.09 \\
$\begin{array}{c}\text { Hosts \& } \\
\text { symptoms }\end{array}$ & 7 & 3.48 & 0.20 & 3 & 5 & 3.91 & 0.09 & 4 & 0.05 \\
$\begin{array}{c}\text { Distribution } \\
\text { Economic } \\
\text { impacts }\end{array}$ & 8 & 3.30 & 0.16 & 3 & 6 & 3.63 & 0.09 & 4 & 0.25 \\
Resistance & 10 & 3.22 & 0.20 & 3 & 8 & 3.54 & 0.10 & 3 & 0.72 \\
Regulations & 11 & 2.88 & 0.20 & 3 & 10 & 3.30 & 0.10 & 3 & 0.41 \\
\hline
\end{tabular}

\subsection{Comparison to Earlier RNAs}

In comparison to the research priorities in 2010, prior research assessments favored more basic research questions, and more emphasis was placed initially on wildland environments (Figure 1 and Figure 2). This is partially a historical artifact and to be expected, since the pathogen was a species new to science in 2000 and was causing dramatic impacts in forests.

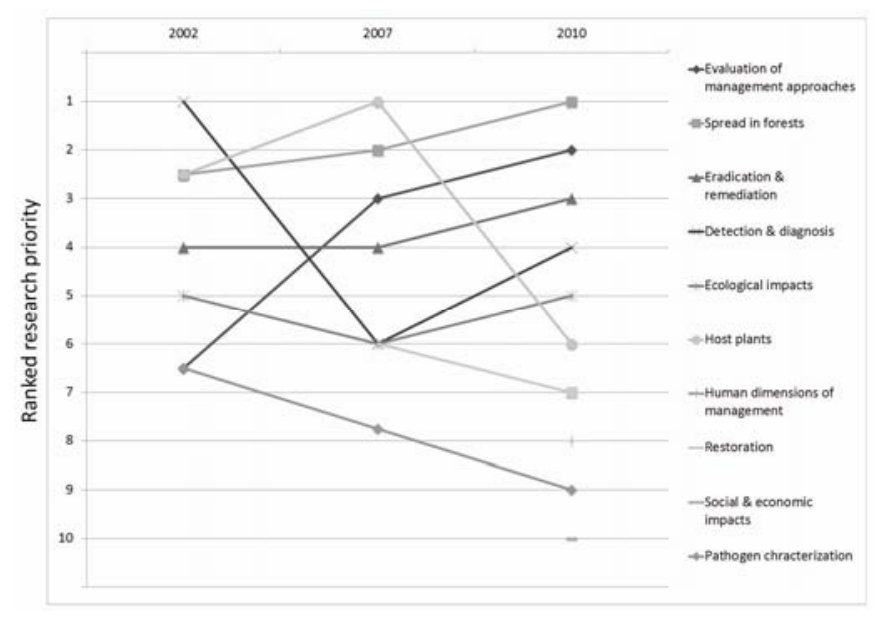

Figure 1. Comparison of wildland research priorities 2002-2010

1 For continuity, the research categories are listed in the same order of prioritization as they appeared in the 2010 rankings (Table1 and Table2). 
2 The 2010 expert and community priorities were condensed into a single number for this comparison across years; some of the priorities have therefore shifted.

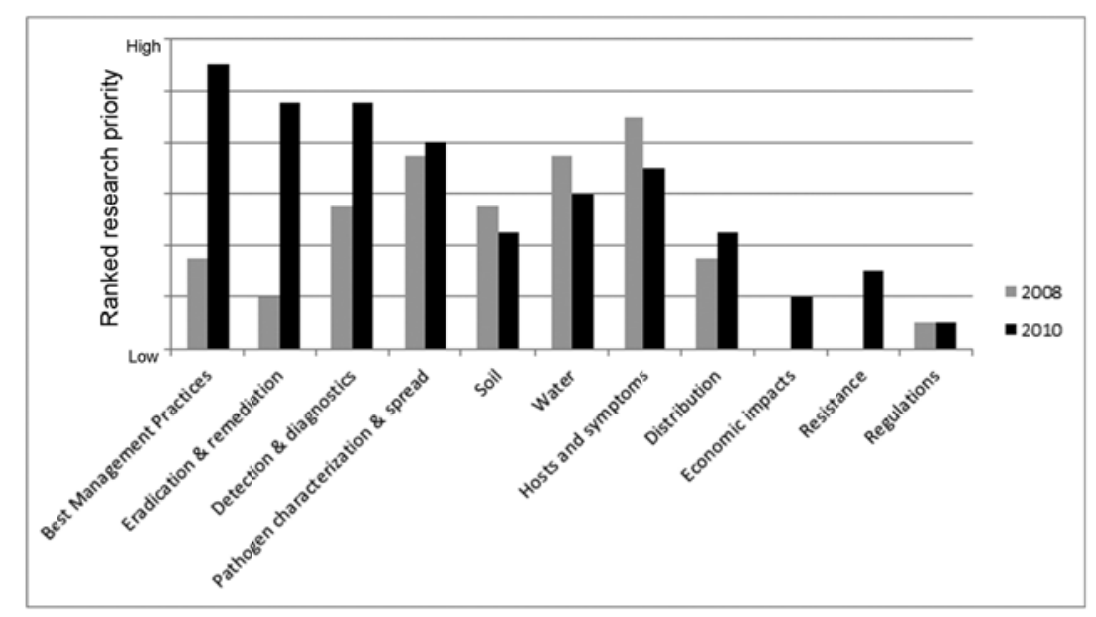

Figure 2. Comparison of nursery research priorities 2008-2010

1 For continuity, the research categories are listed in the same order of prioritization as they appeared in the 2010 rankings (Tables1 and Tables2).

2 The 2010 expert and community priorities were condensed into a single number for this comparison across years; some of the priorities have therefore shifted.

\subsection{Literature Review}

The counts of research articles published on subjects related to P. ramorum within the last decade show that in relation to wildlands, more published research has gone toward the subject of pathogen spread (77) than any other category, followed by detection and diagnostics (53) (Figure 3). Pathogen characterization (37), management (34), and hosts and resistance (32) were all roughly equal in the amount of research attention received. Nursery research has focused most intensively on detection and diagnostics (39), followed by pathogen characterization (30) and pathogen distribution (26) (Figure 4).

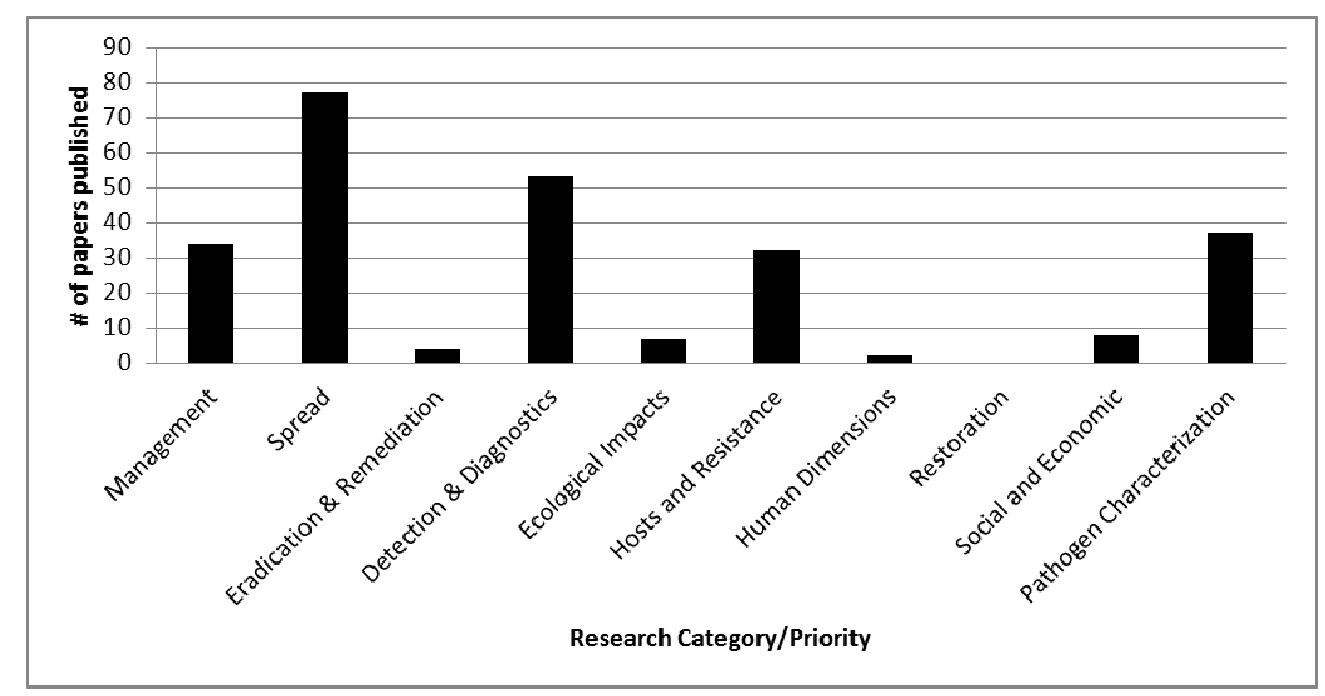

Figure 3. Number of papers published since 2000 per wildland research category identified in 2010 


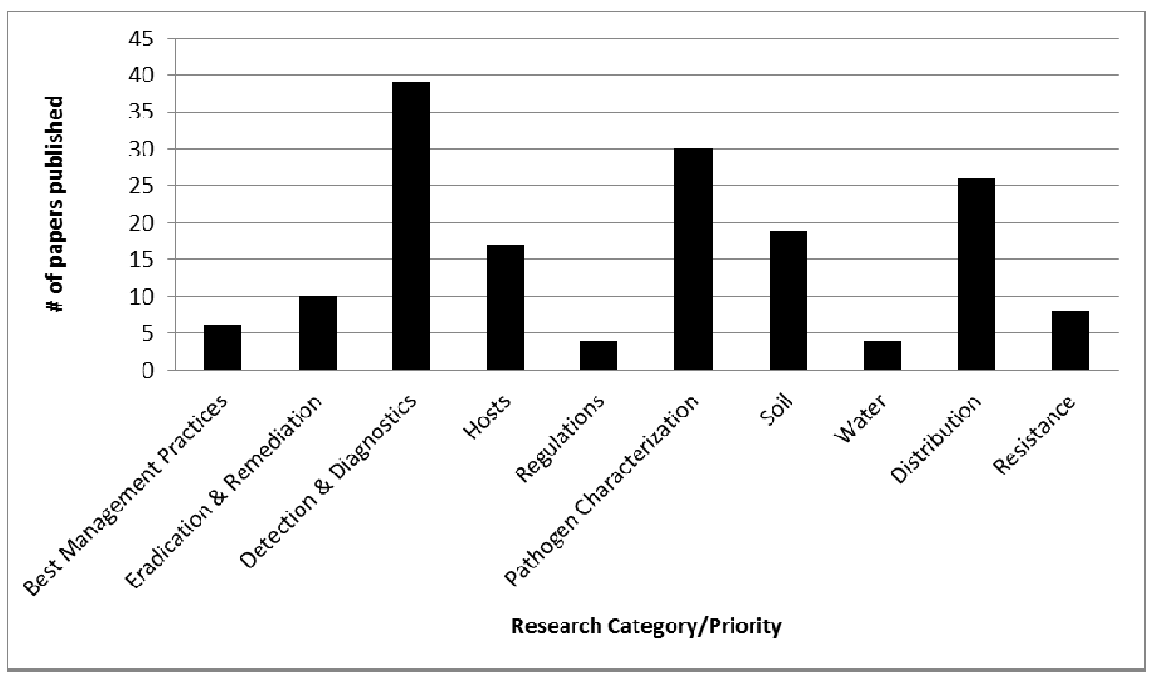

Figure 4. Number of papers published since 2000 per nursery research category identified in 2010

\section{Discussion}

\subsection{Areas of Emphasis and Agreement in 2010}

The expert and community groups agreed to a surprising extent in their choices of research subjects and priorities. However, the groups did differ in some ways, both in wildland and nursery surveys. For example, in the wildland survey the expert group identified management research as the highest priority, while the community group identified research into pathogen spread and into eradication/remediation as higher priorities. In the nursery survey, the two groups differed on the importance of research on "hosts and symptoms"- the only category to generate a statistically significant difference in the nursery survey, with the public group ranking it more highly than the expert group. In both of these cases, we suspect that the differences in ranking may stem from the expert groups' greater familiarity with current knowledge or with issues related to management.

A different situation exists with the prioritization of pathogen spread in forests. In this case, both expert and community groups ranked this category highly as a research gap — surprising considering that this category has produced nearly twice as many research papers over the last decade as any of the others. Although pathologists cannot look at a landscape and predict the timing or extent of future pathogen spread precisely, enough information exists to enable coherent management strategies (Valachovic et al., 2010; Filipe et al., 2011). More research will certainly add important information, but viewed against other needs within the overall research-to-management spectrum, it is interesting why this highly investigated topic remains one of the highest research priorities for survey respondents.

None of the groups identified any issues as being of low or very low priority, with the single exception of the Nursery Experts, who identified "regulations" as low priority. This does not denote lack of support for a regulatory approach to pathogen management, but rather lack of interest in research into the effectiveness or design of the regulations. The high prioritization of almost all research categories resembles the results of Wolf and Kruger (2010) for urban forestry research needs. The issues of lowest perceived importance included "human dimensions of management," "restoration," and "social and economic impacts" for the wildland survey and "economic impacts" and "regulations" for the nursery survey. Even survey respondents who would seemingly have the greatest understanding of and need for these social science topics, such as "government experts" involved in policy and regulation, still did not highly rank those issues. This could be indicative of a lack of appreciation for the way these big-picture issues underlie and inform the highest-prioritized topics, especially management - even though the importance, indeed the necessity, of both economic analyses (Leuschner et al., 1996; Sydnor et al., 2007) and social science (Roe, 1996) for motivating and informing ecosystem management (and attracting funding) has been well established.

\subsection{Evolution of a research program from 2000 to 2010}

In 2002, most concern was directed to: "Where is the problem and how do we know where it will go?", thus the high priority rankings for the categories "Detection and Diagnosis," "Spread," and "Hosts." Emphasis shifted as 
basic research filled in gaps in our understanding of the pathogen. By 2007, the wildland responses were grouped into a few general questions (water detection, survival in soil, host resistance, conifer susceptibility, management tools, restoration, etc.) that fit into categories related to host plants, spread, and management. In 2010, management has emerged as a larger concern; however, as noted above, emphasis continues to be placed on basic questions about pathogen spread and diagnosis/detection, with less emphasis on other applied questions about restoration, ecological impacts, and economic impacts.

In the nursery realm, research issues had previously focused largely on hosts and symptoms and basic questions about the nature of the pathogen. In 2010, the issues for nurseries were finding the pathogen ("Diagnostics and detection") and eradicating it ("Eradication and remediation"), along with better nursery management tools to prevent the introduction, establishment, and spread of the pathogen altogether ("Best Management Practices"). Similar to the wildland results, priorities have moved from simply determining the location of the pathogen (on plants and in substrates) toward managing environments to eradicate or preclude it. To some extent, this indicates a desire on the part of the nursery community to have an alternative to current regulation and a shift to recommended BMPs.

The trend of basic knowledge progressing toward more and more specific arenas of management seems likely to continue. While a well-ordered, systematic research process is critical for the advancement of science and the effective management of natural resources, such a process may inadvertently generate overly specialized viewpoints that may obscure a broad, general understanding of the field. Critiques of scientific specialization are not new; see, for example, C.S. Peirce's 1904 quote in Nubiola (2005), as well as Jaspers (1962). For the $P$. ramorum research program, the wildland survey suggests that community members could be precluded from seeing the bigger, regional picture of forest health management because of their focus on small-scale or single-property eradication - literally not seeing the forest for the trees. Similarly, the tendency to concentrate on enumerating all the ornamental hosts of P. ramorum (well-explored territory) may keep community members from seeing the bigger picture of figuring out how to eliminate the pathogen from individual nurseries and from the trade as a whole. It is, however, appropriate for experts to focus on the small scale as long as research gaps exist, such as those related to soil and potting media.

One outcome of this specialization may be increasing fragmentation of the research program and increased competition for funding. As more specialized management tools and techniques are prioritized for research (e.g., eradication techniques in forests, or fungicide trials in nurseries), there may be fewer opportunities for research to be so basic as to be universally applicable. However, as noted by some of the 2010 RNA participants, many categories and specific research questions are common to both nursery and forest systems and many closely related topics of concern would likely be addressed simultaneously. Finally, this tendency toward smaller, more focused projects was more pronounced in members of the larger "community" rather than the "experts" - i.e., those most likely to be doing research in the future - so too-narrow specialization may not be such an issue.

\subsection{Widening the Picture: from Individual Research Project to Landscape Management}

Basic research is crucial to the management of invasive organisms. Landscape ecologists and epidemiologists have established that for management of invasive threats to be effective across landscapes, the scale of control efforts must match the scale of invasion (Holdenrieder et al., 2004; Gilligan, 2008; Epanchin-Niell\& Hastings, 2010). Basic biological research can determine the scale of invasion and help determine the appropriate scale of necessary control efforts, and these suggestions can then be refined by more applied research (Carter, 2008). However, whether wide-scale control efforts actually occur lies outside the realm of science proper (McPherson, 2004); see Table 3 for a survey of extra-scientific obstacles to wide-scale management efforts.

Although basic research is valuable for its own sake, most grant-providing organizations and agencies do not intend for the basic research they fund to happen in a vacuum. Rather, this research is a stepping-stone toward real-world application. In the case of invasive species, it is logical to regard effective containment, control, or eradication of the invasive problem as this real-world endpoint. Effective control of non-native, invasive species; usually presupposes management activities on a wide spatial scale (Gilligan, 2008; Filipe et al., 2011). As we summarized the results of the 2010 Sudden Oak Death RNA, these questions emerged as primary follow-up concerns: How does the community concerned with this biological invasion move from basic research to coordinated, unified management on landscape, regional, and national scales? How can we maximize the strong investment and consensus in research to enable more applied, landscape-to-regional-level management on the ground? 
Table 3. Extra-scientific (e.g., political, economic, logistical, social) factors that impede wide-scale management of invasive species

\begin{tabular}{|c|c|}
\hline Obstacle to management & Literature source/examples \\
\hline Lack of funding & $\begin{array}{l}\text { Thomson and Fleming, 1991; Simberloff, } \\
2003\end{array}$ \\
\hline $\begin{array}{l}\text { Policy, legal, and environmental issues related to } \\
\text { multiple-resource management }\end{array}$ & Norris, 1985; Thomson and Fleming, 1991 \\
\hline $\begin{array}{l}\text { Lack of coordination between land managers, agencies, and } \\
\text { other institutions }\end{array}$ & $\begin{array}{l}\text { Cannon and Worley, 1980; Simberloff, } \\
\text { 2003; Lawton, } 2007\end{array}$ \\
\hline $\begin{array}{l}\text { Public attitudes toward management actions, conditioned by } \\
\text { past eradication or management failures or environmental } \\
\text { concerns }\end{array}$ & $\begin{array}{l}\text { Keatley Garvey, } 2008 \text { (light brown apple } \\
\text { moth in California); Gottwald et al., } 2001 \\
\text { (citrus canker in Florida); Driscoll, } 2007 \\
\text { (purple loosestrife in northern California); } \\
\text { Simberloff, 2003 (fire ants in the } \\
\text { southeastern U.S.); Geils et al., } 2010 \\
\text { (white pine blister rust in the western } \\
\text { U.S.); Anagnostakis, } 1987 \text { (chestnut blight } \\
\text { in the eastern U.S.) }\end{array}$ \\
\hline Denials that invasive species constitute a problem & Gattuso, 2006; Davis et al., 2011 \\
\hline
\end{tabular}

Many invasive species management efforts have struggled to move from a research-centered worldview, often accompanied by numerous small-scale management attempts, to more widespread, coordinated on-the-ground management over large scales (D'Antonioet al., 2004). Moreover, in some such efforts, researchers and managers have reported low levels of collaboration (Renzet al., 2009). Efforts suggested by the literature to overcome these obstacles include those listed in Table 4.

Table 4. Suggestions from the scientific literature for overcoming obstacles to management of invasive species. For further information, see Walton and Gray, 1991; Thompson and Fleming, 1991; and Lawton, 2007.

\begin{tabular}{|c|c|}
\hline Suggestion & Literature source/Examples \\
\hline $\begin{array}{l}\text { Embedding proposals for research in an adaptive } \\
\text { management cycle }\end{array}$ & Holling\&Meffe, 1996; Bell et al., 2008 \\
\hline More intensive outreach efforts (in general) & Mills et al., 2002; Szaroet al., 2005; Moser et al., 2009 \\
\hline $\begin{array}{l}\text { More intensive outreach from researchers to land } \\
\text { managers }\end{array}$ & Carter, 2008; JFSP, 2010 \\
\hline $\begin{array}{l}\text { More intensive outreach from researchers to } \\
\text { policymakers and regulators }\end{array}$ & Continental Dialogue, 2010 \\
\hline $\begin{array}{l}\text { More intensive outreach from researchers to the } \\
\text { general public }\end{array}$ & $\begin{array}{l}\text { COMTF, 2011; MSU \& USDAFS, 2011; } 100^{\text {th }} \text { Meridian } \\
\text { Initiative, 2011 }\end{array}$ \\
\hline $\begin{array}{l}\text { Involving the public in more large-scale land } \\
\text { management decisions, e.g., through "consensus } \\
\text { conferences" }\end{array}$ & Middendorf\& Busch, 1997 \\
\hline Increased coordination between agencies & Moser et al., 2009 \\
\hline $\begin{array}{l}\text { Streamlining procedures for compliance with } \\
\text { environmental regulation to enable quick action and } \\
\text { avoidance of litigation }\end{array}$ & Norris, 1985 \\
\hline
\end{tabular}

Surveying the sudden oak death RNA and the results of ten years of research and management, we see that the $P$. ramorum scientific community has made substantial progress along the path from basic research to active management. In a small amount of time, scientists have learned a tremendous amount about the biology and 
ecology of $P$. ramorum, and the importance of management is widely recognized within the research community. The $P$. ramorum world is characterized by good coordination and communication between the various segments of the land management and research communities, as well as good outreach to the public and resource managers. There have been attempts to manage through regulation (HRI P. ramorum Industry Working Group, 2008; COMTF, 2008a), and regional-scale eradication attempts are ongoing in Oregon and the UK (Goheen et al., 2004; Kanaskieet al., 2009a, 2009b; Hansen et al., 2008; Forestry Commission Great Britain, 2011). In California, the pathogen became established in wildlands faster than eradication attempts could be mounted, but we have observed numerous small-scale neighborhood or single-property management attempts at the wildland-urban interface (Alexander \& Lee, 2010) as well as ongoing management experiments that are slowly establishing the efficacy of individual management techniques at a larger scale (Valachovic et al., 2008; Garbelotto \& Schmidt, 2009; Swiecki\& Bernhardt, 2009).

Nevertheless, the necessary conditions to enable coordinated, rapid management at the scales recommended by epidemiologists do not yet exist. In general, funding and legal support for the management programs mentioned above have been on a year-to-year, ad hoc basis. Management funding, although present and substantial in some years, has not remained stable from year to year and so cannot guarantee long-term stability for eradication or containment. In such an environment, the existence of landscape-scale management efforts typically depends on the initiative of a few energetic mavericks rather than being the default option. Such a default option would require a well-prepared management infrastructure that has already dealt with funding, legal, and timing issues. Such an infrastructure in turn would presuppose the formulation of policies that in some cases might run the risk of nullifying or superseding existing environmental policies (for example, by the creation of programmatic environmental impact documents that clear the way for quick action by prioritizing $P$. ramorum management), but this may be appropriate given the nature of the potential harm caused by the invasive species of concern (Franklin \& Johnson, 2011).

This kind of infrastructure would require centralized policy focused on eradication or containment, albeit with substantial public debate and potential resistance from some constituencies. In contrast, Santos et al. (2011) argue, using global warming as an example, that large, centralized policy groups may not achieve important public policy goals as effectively as decentralized networks of small groups. This generalization varies according to many factors, including the degree of risk that is attached to the failure of actors to cooperate. We contend that failure to adequately manage non-native, invasive forest pests and pathogens such as $P$. ramorum constitutes a risk of very high order with the potential to shift the function, dynamics, and habitability of entire ecosystems (sensuLindenmayeret al., 2011; see also Brasier, 2008).Reviewing the checkered history of invasive species policies, including those pertaining to plant diseases, reveals at least a couple of paradoxes inherent in moving from research to wide-scale management for emerging diseases: 1) Small groups may be better able to get things done, but leaving management to small groups poses an inherent danger of incomplete treatment in the case of infectious disease, analogous to the problem of vaccination with human viral diseases; and 2) Effective management depends on attaining adequate knowledge of pathogen biology, but also on taking the swiftest action possible. Thus, it would appear that both small, localized groups and large, centralizedgroups hold the keys to adequate response, with the challenge lying in how to achieve the appropriate mix.

From our foregoing review of the state of sudden oak death research and the considerations immediately above, we draw some provisional conclusions that concern this particular disease but may also apply to other invasive, infectious plant diseases:

1) When a new disease emerges, the point of emergence (the San Francisco Bay area in the case of sudden oak death) will likely experience complete invasion while researchers investigate the pathogen's basic biology. Once rudimentary knowledge is achieved, management at new points of emergence should be swift and aggressive, even if undertaken on the basis of incomplete knowledge. Such management requires a sustained focus on policy development, at least at the local level, so that management infrastructure can be in place when the pathogen emerges in new locations.

2) Because public participation and consent-including the participation and consent of legislators-are important to regional disease management, a premium should be placed on integrating the scattered pieces of the research literature into easily digestible forms.

3) Researchers may want to consider increasing the focus on the big-picture issues that they currently hold at low priority, such as social issues, economic impacts, and regulation effectiveness. These issues are essential for educating the public on the full costs of failing to manage invasive organisms.

Despite the notable success of the California Oak Mortality Task Force and of the numerous other regional groups in Oregon, the UK, and the eastern U.S. devoted to sudden oak death outreach and education, we feel it 
imperative that the focus on coordination and education of disparate groups be tightened even further. Our RNA results suggest that groups concerned with bridging the gap between research and application need to turn their attention to recruiting adequate numbers of well-qualified professionals in such fields as education, journalism, marketing, law, and policy formulation and advocacy, among other professions adept at translating the languages of science into those of the marketplace of popular ideas. Given the hundreds of publications already generated by $P$. ramorum researchers, it logically follows that neither experts nor community members will be able to keep up and follow the big picture without help from these kinds of technology transfer professionals.From the other side, researchers themselves may not be paying close enough attention to the policies, such as changes to regulations, surrounding the invasive species they are studying. It may be important for this affected population of scientists and managers to become more involved in advocacy issues. Researchers, ecosystem managers, and especially policy makers must pay sustained attention to these needs to ensure that adequate funds are appropriated for these kinds of contributors as early on in the discovery of a biological invasion as possible — or society will live with the consequences.

\section{Conclusions}

The $P$. ramorum research program appears to be following a pattern shown with other invasive species where an early focus on basic biology evolves toward more management-oriented questions. The open communication between P. ramorum researchers and out to the larger informed community has fostered more focused agreement on which issues to prioritize for funding. This communication must continue, and be strengthened, in order to make the leap from a list of smaller, individual research questions toward coordinated, large-scale management efforts bringing researchers, managers, and policy-makers together. Research programs should include measures of social impacts, not just ecological impacts, if invasive species are to remain relevant and funded. The interpretation and transfer of information collected by research programs must also be included in this effort.

\section{References}

$100^{\text {th }}$ Meridian Initiative. (2011). Homepage. Retrieved fromhttp://100thmeridian.org/

Alexander, J., Lee, C. A. (2010). Lessons learned from a decade of sudden oak death in California: evaluating local management. Environmental Management, 46, 315-328. http://dx.doi.org/10.1007/s00267-010-9512-4

Anagnostakis, S. I. (1987). Chestnut blight: the classical problem of an introduced pathogen. Mycologia, 79 , 23-27. http://dx.doi.org/10.2307/3807741

Bell, F. W., Baker, J. A., Bruemmer, G., Pineau, J., \& Stinson, A. (2008). The Canadian Ecology Centre-Forestry Research Partnership: implementing a research strategy based on an active adaptive management approach. The Forestry Chronicle, 84, 666-677. http://dx.doi.org/10.5558/tfc84666-5

Brasier, C. M. (2008).The biosecurity threat to the UK and global environment from international trade in plants.Plant Pathology, 57, 792-808. http://dx.doi.org/10.1111/j.1365-3059.2008.01886.x

California Oak Mortality Task Force (COMTF). (2007). Research Needs Assessment for Phytophthora ramorum in wildlands. Retrieved from http://nature.berkeley.edu/comtf/pdf/SOD3RNAsummary.pdf

California Oak Mortality Task Force (COMTF). (2008a). USA Phytophthora ramorum nursery chronology. Retrieved from http://www.suddenoakdeath.org/pdf/Nursery_ChronologyCurrent.pdf

California Oak Mortality Task Force (COMTF). (2008b). Nursery Committee research needs. Retrieved from http://www.suddenoakdeath.org/pdf/NurseryResearchNeedsList3-9-08.pdf

California Oak Mortality Task Force (COMTF). (2011). COMTF homepage. Retrieved from http://www.suddenoakdeath.org

Cannon, W. N., Jr. Worley, D. P. (1980). Dutch elm disease: performance and costs. USDA Forest Service, Northeastern Forest Experiment Station, Broomall, PA.

Carter, S. (2008). Research and policy implementation for more equitable and sustainable use of common-pool resources. Society and Natural Resources, 21, 152-159. http://dx.doi.org/10.1080/08941920701681508

Continental Dialogue on Non-native Forest Insects and Diseases. (2010). Continental dialogue homepage. Retrieved from http://www.continentalforestdialogue.org/

D'Antonio, C. M., Jackson, N. E., Horvitz, C. C., \& Hedberg, R. (2004). Invasive plants in wildland ecosystems: merging the study of invasion processes with management needs. Front. Ecol. Environ, 2, 513-521. http://dx.doi.org/10.1890/1540-9295(2004)002[0513:IPIWEM]2.0.CO;2

Davis, M. A., Chew, M. K., Hobbs, R. J., Lugo, A. E., Ewel, J. J., Vermeij, G. J., Brown, J. H., Rosenzweig, M. 
L., Gardener, M. R., Carroll, S. P., Thompson, K., Pickett, S. T. A., Stromberg, J. C., Del Tredici, P., Suding, K. N., Eherenfeld, J. G., Grime, J. P., Mascaro, J., \& Briggs, J. C. (2011). Don’t judge species on their origins. Nature, 474, 153-154. http://dx.doi.org/10.1038/474153a

Driscoll, J. (2007). Parks, county hit with lawsuit over loosestrife spraying. Eureka Times-Standard.

Epanchin-Niell, R. S., \& Hastings, A. (2010). Controlling established invaders: integrating economics and spread dynamics to determine optimal management. Ecol. Lett, 13, 528-541. http://dx.doi.org/10.1111/j.1461-0248.2010.01440.x

Filipe, J. A. N., Cobb, R. C., Meentemeyer, R. K., Lee, C. A., Valachovic, Y. S., Cook, A. R., Rizzo, D. M., \& Gilligan, C. A. (2012). Landscape epidemiology and control of pathogens with cryptic and long-distance dispersal: sudden oak death in northern Californian forests. PLoSComput.Biol, 8(1). e1002328. http://dx.doi.org/10.1371/journal.pcbi.1002328

Forestry Commission Great Britain.(2011). Phytophthora ramorum in larch trees—update.

Franklin, J. F., \& Johnson, K. N. (2011). Societal challenges in understanding and responding to regime shifts in forest landscapes. PNAS, 108, 16863-16864. http://dx.doi.org/10.1073/pnas.1114045108

Garbelotto, M., \& Schmidt, D. J. (2009). Phosphonate controls sudden oak death pathogen for up to 2 years. California Agriculture, 63, 10-17. http://dx.doi.org/10.3733/ca.v063n01p10

Gattuso, D. J. (2006). Invasive species: animal, vegetable or political? National Policy Analysis, 5, 44.

Geils, B. W., Hummer, K. E., \& Hunt, R. S. (2010). White pines, Ribes, and blister rust: a review and synthesis. Forest Pathology, 40, 147-185. http://dx.doi.org/10.1111/j.1439-0329.2010.00654.x

Gilligan, C. A. (2008). Sustainable agriculture and plant diseases: an epidemiological perspective. Philos. T. Roy. Soc. B, 363, 741-759. http://dx.doi.org/10.1111/j.1439-0329.2010.00654.x

Goheen, E., Hansen, E., Kanaskie, A., McWilliams, M., Osterbauer, N., Sutton, W., \& Rehms, L. (2004). An eradication strategy for Phytophthora ramorum in Oregon forests.Phytopathology, 94(6). S35.http://dx.doi.org/10.1094/PHYTO.2004.94.6.S1

Gottwald, T. R., Hughes, G., Graham, J. H., Sun, X., \& Riley, T. (2001). The citrus canker epidemic in Florida: the scientific basis of regulatory eradication policy for an invasive species. Phytophathology, 91, 30-34. http://dx.doi.org/10.1094/PHYTO.2001.91.1.30

Hansen, E. M., Kanaskie, A., Prospero, S., McWilliams, M., Goheen, E. M., Osterbauer, N., Reeser, P., \& Sutton, W. (2008). Epidemiology of Phytophthora ramorum in Oregon tanoak forests. Canadian Journal of Forest Research, 38, 1133-1143. http://dx.doi.org/10.1139/X07-217

Hintze, J. L. (2007). Number Cruncher Statistical Systems (NCSS). Kaysville, Utah.

Holdenrieder, O., Pautasso, M., Weisberg, P. J., \& Lonsdale, D. (2004). Tree diseases and landscape processes: the challenge of landscape pathology. TRENDS Ecol. Evol, 19, 446-452. http://dx.doi.org/10.1016/j.tree.2004.06.003

Holling, C. S., Meffe, G. K. (1996). Command and control and the pathology of natural resource management.Conservation Biology, 10, 328-337. http://dx.doi.org/10.1046/j.1523-1739.1996.10020328.x

HRI P. ramorum Industry Working Group. (2008). Nursery industry best management practices for Phytophthora ramorum to prevent the introduction or establishment in California nursery operations, Version 1.0. Sacramento, CA.

Jaspers, K. (1962). Truth and science. Philos. Today, 6, 200-211.

Joint Fire Science Program (JFSP). (2010). The JFSP Knowledge Exchange Consortia: Vision and Goals.

Kanaskie, A., Goheen, E. Hansen, E. Osterbauer, N., McWilliams, M., Schultz, R., Savona, S., Sutton, W., \& Reeser, P. (2009a). Early detection and eradication of Phytophthora ramorum (sudden oak death) in Oregon forests. Phytopathology, 99, S61. http://dx.doi.org/10.1094/PHYTO.2009.99.6.S1

Kanaskie, A., Goheen, E. M., Hansen, E. M., Sutton, W., Reeser, P. O., \& sterbauer, N. (2009b). Monitoring the effectiveness of Phytophthora ramorum eradication treatments in southwest Oregon tanoak forests.Phytopathology, 99, S61. http://dx.doi.org/10.1094/PHYTO.2009.99.6.S1

Keatley Garvey, K. (2008). Plans to control light brown apple moth stir controversy. California Agriculture, 62, 55-56. http://dx.doi.org/10.3733/ca.v062n02p55 
Kliejunas, J. T. (2010). Sudden oak death and Phytophthora ramorum: A Summary of the Literature. PSW-GTR-230, Pacific Southwest Research Station, Forest Service, U.S. Department of Agriculture, Albany, CA.

Lawton, J. H. (2007). Ecology, politics and policy.Journal of Applied Ecology, 44, 465-474. http://dx.doi.org/10.1111/j.1365-2664.2007.01315.x

Leuschner, W. A., Young, J. A., Walden, S. A., \& Ravlin, F. W. (1996). Potential benefits of slowing the gypsy moth's spread.Southern Journalof Applied Forestry, 20(2), 65-73.

Lindenmayer, D. B., Hobbs, R. J., Likens, G. E., Krebs, C. J., \& Banks, S. C. (2011). Newly discovered landscape traps produce regime shifts in wet forests. PNAS, 108, 15887-15891. http://dx.doi.org/10.1073/pnas.1110245108

Linn, R. L. (1986). Educational testing and assessment: research needs and policy issues. American Psychologist, 41, 1153-1160. http://dx.doi.org/10.1037/0003-066X.41.10.1153

Mascheretti, S., Croucher, P. J. P., Vettraino, A., Prospero, S., \& Garbelotto, M. (2008). Reconstruction of the sudden oak death epidemic in California through microsatellite analysis of the pathogen.Phytophthora ramorum.MolecularEcology, 17(11), 2755-2768. http://dx.doi.org/10.1111/j.1365-294X.2008.03773.x

McPherson, G. R. (2004). Linking science and management to mitigate impacts of nonnative plants.WeedTechnol,18(1),

1185-1188.http://dx.doi.org/10.1614/0890-037X(2004)018[1185:LSAMTM]2.0.CO;2

Meentemeyer, R. K., Rank, N. E., Shoemaker, D. A., Oneal, C. B.,Wickland, A. C.,Frangioso, K. M., \& Rizzo, D. M. (2008). Impact of sudden oak death on tree mortality in the Big Sur ecoregion of California.Biological Invasions, 10(8), 1243-1255. http://dx.doi.org/10.1007/s10530-007-9199-5

Michigan State University (MSU) and USDA Forest Service (USDA-FS). (2011). Emerald ash borer website.Retrieved fromhttp://www.emeraldashborer.info

Middendorf, G., Busch, L. (1997). Inquiry for the public good: democratic participation in agricultural research. Agriculture and Human Values, 14, 45-57. http://dx.doi.org/10.1023/A:1007398913221

Mills, T. J., Smythe, R. V., Diaz-Soltero, H. (2002). Achieving science-based national forest management decisions while maintaining the capability of the research and development program. USDA Forest Service, PSW Research Station, Station Misc., Albany, CA.

Moser, W. K., Barnard, E. L., Billings, R. F.,Crocker, S. J., Dix, M. E., Gray, A. N., Ice, G. G., Kim, M. S., Reid, R., Rodman, S. U., \& McWilliams, W. H. (2009). Impacts of nonnative invasive species on US forests and recommendations for policy and management.Journal of Forest, 107(6), 320-327.

Norris, L. A. (1985). Implementing forest pest management practices in the USA: problems and solutions. The ForestryChronicle, 61(3), 243-246. http://dx.doi.org/10.5558/tfc61243-3

Nubiola, J. (2005). The classification of the sciences and cross-disciplinarity.Transactions of the Charles $S$. Peirce Society, 41(2), 271-282.

Pacific Southwest Research Station (PSW). (2002). Sudden oak death: a 5-Year Research Plan Addressing the Emerging Threat. USDA Forest Service, Pacific Southwest Research Station, Albany, CA.

Renz, M., Gibson, K. D., Hillmer, J., Howe, K. M., Waller, D. M., Cardina, J. (2009). Land manager and researcher perspectives on invasive plant research needs in the midwestern United States. Invasive Plant Science and Management, 2, 83-91. http://dx.doi.org/10.1614/IPSM-08-109.1

Rizzo, D. M., Garbelotto, M., Davidson, J. M., Slaughter, G. W., Koike, S. T. (2001). A new Phytophthora canker disease as the probable cause of Sudden Oak Death in California. Phytopathology, 91(6): S76. http://dx.doi.org/10.1094/PHYTO.2001.91.6.S1

Roe, E. (1996). Why ecosystem management can't work without social science: an example from the California northern spotted owl controversy. Environmental Management, 20(5), 667-674. http://dx.doi.org/10.1007/BF01204138

Sansford, C. E., Inman, A. J., Baker, R., Brasier, C., Frankel, S., de Gruyter, J., Husson, C., Kehlenbeck, H., Kessel, G., Moralejo, E., Steeghs, M., Webber, J., \& Werres, S. (2009).Report on the risk of entry, establishment, spread and socio-economic loss and environmental impact and the appropriate level of management for Phytophthora ramorum for the EU. Deliverable Report 28. Sand Hutton, York, UK: Forest 
Research, Central Science Laboratory. EU Sixth Framework Project, RAPRA. 310 p.

Santos, F. C., \& Pacheco, J. M. (2011). Risk of collective failure provides an escape from the tragedy of the commons. PNAS, 108(26), 10421-10425. http://dx.doi.org/10.1073/pnas.1015648108

Simberloff, D. (2003). Eradication-preventing invasions at the outset.Weed Science, 51, 247-253.http://dx.doi.org/10.1614/0043-1745(2003)051[0247:EPIATO]2.0.CO;2

Swiecki, T. J., \& Bernhardt, E. A. (2009). Assessing methods to protect susceptible oak and tanoak stands from sudden oak death. In S.J. Frankel, J.T. Kliejunas, and K.M. Palmieri, (Tech. Coords.). Proceedings of the Sudden Oak Death Fourth Science Symposium (pp. 236-238). USDA Forest Service, Pacific Southwest Research Station, PSW-GTR-229, Albany, CA.

Sydnor, T. D., Bumgardner, M., \& Todd, A. (2007). The potential economic impacts of emerald ash borer (Agrilusplanipennis) on Ohio, U.S., communities.Arboriculture and Urban Forestry, 33(1), 48-54.

Szaro, R. C., Boyce Jr., D. A., \& Puchlerz, T. (2005). The challenges associated with developing science-based landscape scale management plans. Landscape Urban Plan, 72, 3-12. http://dx.doi.org/10.1016/j.landurbplan.2004.09.011

Thomson, A. J., \& Fleming, R. (1991). Legislative and policy limits to successful integrated pest management in Canada's forests. The Forestry Chronicle, 67(5), 493-499.http://dx.doi.org/10.5558/tfc67493-5

USDA Animal and Plant Health Inspection Service (APHIS). (2011). APHIS Phytophthora ramorum Program 2011, 3rd Quarter Summary.

Valachovic, Y. Lee, C. Marshall, J. \& Scanlon, H. (2008). Wildland management of Phytophthora ramorum in northern California forests.In S.J. Frankel, J.T. Kliejunas, and K.M. Palmieri (Eds.). Proceedings of the Sudden oak death Third Science Symposium (pp. 305-312). USDA Forest Service, Pacific Southwest Research Station, PSW-GTR-214, Albany, CA.

Valachovic, Y., Lee, C., Marshall, J., \& Scanlon, H. (2010). Forest treatment strategies for Phytophthora ramorum.In S.J. Frankel, J.T.,Kliejunas, \& K.M. Palmieri (Tech. Coords.).Proceedings of the Sudden Oak Death Fourth Science Symposium (pp. 239-248). USDA Forest Service, Pacific Southwest Research Station, PSW-GTR-229, Albany, CA.

Walton, D. W. H., \& Gray, A. J. (1991). Ecology and government policies. TRENDS Ecol. Evol, 6, 144-145. http://dx.doi.org/10.1016/0169-5347(91)90054-2

Webber, J. F., Mullett, M., \& Brasier, C. M. (2010). Dieback and mortality of plantation Japanese larch (Larixkaempferi) associated with infection by Phytophthora ramorum. New Disease Reports, 22, 19. http://dx.doi.org/10.5197/j.2044-0588.2010.022.019

Werres, S., Marwitz, R., Man in 't Veld, W.A., De Cock, A.W.,Bonants, P. J. M., De Weerdt, M.,Themann, K., I lieva, E., \& Baayen, R. P. (2001). Phytophthora ramorum sp. nov: a new pathogen on Rhododendron and Viburnum. Mycological Research, 105(10), 1155-1165. http://dx.doi.org/10.1016/S0953-7562(08)61986-3

Wolf, K. L., \& Kruger, L. E. (2010). Urban forestry research needs: A participatory assessment process. Journal of Forestry, 108, 39-44. 